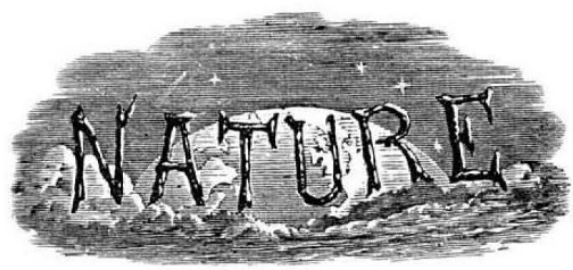

SATURDAY, JUNE 2I, I930.

\section{CONTENTS. PAGE}

Recruitment in the Colonial Services . . . 917 How Fire Became Known. By Henry Balfour, F.R.S. 920 Preparing Estimates for Ships . . . . . 921 Diatoms : Satis superque! By G. T. Harris . . 922 Our Bookshelf

Letters to the Editor:

Science and Philosophy.-Wilfred Trotter . . 924

Developmental Mechanics of Chicken and Duck. Embryos.-C. H. Waddington . .

Researches on the X-Ray Spectrum of Sulphur. -Dr. Osvald Lundquist . . . . .

The Binding Energy of Some Organic Compounds.-Louis S. Kassel . . . .

Negative Attenuation of Wireless Waves.-J. A. Ratcliffe and F. W. G. White. . .

New Spectrum of the Hydrogen Molecule.- Dr. J. J. Hopfield

Association of Stimuli in the Development and Function of the Nervous System. - R. L. Worrall

The Neon Lamp as a Glow Relay.--L. Bellingham Digging' in Rowing. - Dr. Harold Jeffreys, F.R.S. . . . .

The Accuracy of a Moth--Sir Flinders Petrie, F.R.S.

The 1851 Exhibition Commissioners and their Work. Tar Cancer

Obituary :

Dr. Fridtjof Nansen. By Dr. Hugh Robert Mill . 933

Dr. Frank R. Blaxall. By Prof. R. T. Hewlett . 944

News and Views . . . . . . . . 944

Research Items . . . . . . . 950

Photo-Electric Cells. By Dr. Allan Ferguson . $\quad .953$

New Recording Anemometers . . . . . 954

Atlantic and Pacific Land-Bridges . . . . 954

Technical Teachers in Conference . . . . 955

University and Educational Intelligence . . . . 956

Historic Natural Events . . . . . . . 956

Societies and Academies . $\quad . \quad$. . . . . 957

Official Publications Received . . . . . . . $\quad .959$

Diary of Societies . . . . . . . . 960

SUPPLEMENT.

Recent Discoveries of Fossil Man. By Sir Arthur Keith, F.R.S.

Editorial and Publishing Offices:

MACMILLAN \& CO., LTD.,

ST. MARTIN'S STREET, LONDON, W.C. 2.

Editorial communications should be addressed to the Editor.

Advertisements and business letters to the Publishers.

Telephone Number: GERRARD 8830.

Telegraphic Address: PHUSIS, WESTRAND, LONDON.

\section{Recruitment in the Colonial Services.}

A SHORT time ago a Committee was appointed, A under the chairmanship of Sir Warren Fisher, to report on the "System of Appointment in the Colonial Office and the Colonial Services"; its report, which has been recently issued, merits careful consideration. In an opening section attention is directed to the extraordinary diversity of the territories administered by the Colonial Office, covering an area of two million square miles, practically all within the tropics, with a population of nearly fifty millions. Although often alluded to as the 'Colonial Service', in effect there is no such thing, as the Colonial Secretary has to deal with the affairs of more than fifty distinct governments, ruling territories in size from as large as Central Europe down to remote island groups; conditions of life, material equipment, and economic factors being entirely dissimilar.

Recruitment to fill the government posts in these diverse governments has developed in the past in a haphazard fashion under varying conditions, depending more on the ideas of a local governor for the time being than upon those of the authorities in Great Britain. Since the Armistice, matters have greatly improved and the number of posts has increased. In 1909 the appointments made by the Colonial Office numbered 657; in 1929 they rose to 1076, and this in spite of the fact that many classes of appointments, which were normally filled from Great Britain twenty years ago, are now staffed locally. But the Committee insists on the fact that this is not merely a matter of numbers. "Modern conditions demand also a generally higher standard of personal, educational, and professional qualifications, and in addition the employment of men with scientific and special attainments of a kind not previously to be found in the Colonial Service." It is the Committee's recommendations on this latter part of the problem which it is proposed to consider here.

It will be necessary, however, to summarise briefly the excellent exposition given in the Report of the present system of appointment to the various Colonial Services (it is not proposed to dwell on the internal administration of the Office at home), and the recommendations made for its improvement. Apart from local recruitment, the selection of home candidates for employment in the Colonial Services is made in four chief ways: (a) The Civil Service Commissioners in London hold periodical examinations for the selection of eandidates for Eastern Cadetships (administrative appointments in Ceylon,

No. 3164, VoL. 125] 
Malaya, Hong-Kong, etc.), for the Ceylon police and for the post and telegraph services in Nigeria and the Gold Coast ; $(b)$ the Crown Agents to the Colonies select and appoint on behalf of Government candidates for technical posts, such as railways, public works, and so on, the selected men serving for a term of years; $(c)$ the Private Secretary (Appointments) to the Secretary of State, aided by a strong staff, selects and recommends to the Secretary of State outside candidates for a first appointment in the Services; (d) other departments of the Home Government are asked, where necessary, to select from their staffs men with the desired qualifications to fill certain appointments overseas. These departments are the War Office, Post Office, Customs and Education, Home Office and Air Ministry.

It will be evident from the above résumé how varied have been the methods which have grown up with the object of securing quantity, quality, and variety of the staff required to carry on the great area administered from the Colonial Office.

We are here concerned with the great variety of appointments, by far the larger number annually, the selection for which is carried out, and, as the Committee emphatically emphasises, admirably carried out, by the Private Secretary (Appointments) and his staff. The Private Secretary and staff have always been able to obtain the advice and assistance of specialist advisers, both from the Colonial Office and the universities and from men of eminence in various professions, and lastly from senior Colonial officials on leave or recently retired. The Committee places on record that the selection of candidates has at all times been undertaken with the greatest care and that the Colonial Governors have expressed entire approval of the type sent out. The Committee is also at pains to show that the idea, which has prevailed in some quarters, that Oxford and Cambridge have been specially favoured in this selection is not borne out by facts. The bulk of the appointments in administration have gone, for various demonstrable reasons, to these two universities; but London and the Scottish universities have provided the largest number of men for appointments in medicine and scientific departments, Edinburgh being specially mentioned as " the principal source" for forestry.

Whilst fully acknowledging the successful manner in which the selection of candidates is carried out, the Committee considers it undesirable that it should continue to be performed by a staff of private secretaries to the Secretary of State. It recommends that this staff should cease to be in the position of private secretaries and that the appointments branch should be incorporated as a permanent part of the Personnel Division of the Colonial Office. In addition, it is recommended that a Colonial Service Appointment Branch, consisting of a chairman and two members nominated by the Civil Service Commissioners, should be set up as a standing independent branch for the final selection of candidates whose names are put forward by the appointments branch, and that the names of those selected be then submitted to the Secretary of State, on whose authority the appointments will be made. It is also suggested that the promotions branch should be reorganised on a smaller seale and be a section of the Personnel Division. There can be little doubt that these are excellent suggestions, and if put into effect they will greatly strengthen the hands both of selectors for first appointments and also of those dealing with that important question of promotion. On the able recommendations of the Committee on the latter question space will not permit further digression; but in the future interest of the Service they merit careful consideration.

One other recommendation of the Committee requires mention before the scientific services are considered. The question of the unification of the Colonial Service is discussed. The Committee points to the hardships of officers on small cadres in the smaller dependencies, and admits all the objections which have been put forward-differences of salary, leave, pension, climate, customs and language of the people, and so forth; it recognises the reluctance of Governors and others to any change. After a consideration of all the objections, the Committee remains convinced of the importance of unification and recommends that a single Colonial Service should be formed and that, within this larger whole, unified special services should be organised, such as agriculture, forests, medicine, education, and so forth. As the Committee correctly points out, this issue is of the very first importance: "Much of the information on which it rests cannot be present in the minds of Governors or their advisers overseas, since it relates particularly to questions of home recruitment and to the difficulties of individual Colonies".

The question of the technical and specialist research officers remains to be considered. The Committee states that

" many of the officers appointed to scientific and technical services such as agriculture, forestry, veterinary, medical, and so forth, are qualified to undertake research work of a fundamental character, and some officers are appointed in the first instance 
for the specific purpose of carrying out research work on urgent problems confronting a particular service. In the ordinary course, however, an officer appointed to the agricultural service with special knowledge of plant diseases or insect pests, would rank for promotion in the higher grades in that service along with officers engaged in more general and less systematised duties, and would not necessarily confine himself to worl of a specialised character throughout his service."

The statement that "many" of the officers appointed to the above services " are qualified to undertake research work of a fundamental character" would, for some of the services, scarcely be admitted at the universities. Twenty per cent would probably be too high a percentage. Experience has also shown that a young officer, on first appointment, should have a few years of executive work before being detailed for research. This will prevent his making recommendations, when he takes up research, which the executive officer knows to be impracticable. But this type of research officer, as the Committee points out, belongs to a definite service, will go up the grades of that service, will not necessarily confine himself to research all his service, and has a chance of securing the prizes of his own service. His social position is also assured as a member of a service.

The other type of research officer is perhaps of even greater importance--the whole-time specialist. As the Committee must have realised, this type has so far received scant attention. His value is not called in question. He is in demand. The universities could say in how great demand. They are aware that Government has now to compete in this market in some directions with the wide-awake commercial people. These specialist research officers are selected on the understanding that their whole service will be devoted to their particular line of research. It is contemplated that their work will be of such a character that any results they may obtain will be applicable in many parts of the Colonial Empire. Some of them may find it practicable to pursue their investigations in one particular research institution. Others may find it necessary to conduct their researches in different parts of the Empire, attached either to a research station or to a scientific department. In the normal course of things it is neither to be expected nor would it be desirable that their advancement should be conditioned by the occurrence of vacancies in the higher ranks of services other than their own. The Committee states that "it does not follow that such a service should be graded like other colonial services, for each individual in it must determine his own line of research in his particular sphere of work". In this connexion the Committee says:

"In our opinion Research Officers should be encouraged by means of special inducements in the way of salaries and other terms of service to continue their long-range investigations. These terms should, in our opinion, be at least equal to those which they would be likely to obtain if they were prepared to abandon purely research work for more general duties."

Clearly there are considerations other than salaries to be taken into account in dealing with the research officers, and we should have preferred the Committee to have been more specific in its references to this class. It would be disastrous for recruitment if the research officer were to remain 'no man's child', which would mean that he would not enjoy the social position which attaches to the services in the Empire-circles overseas (and is of importance out there). The man may not care about this, but when he marries his wife will, and Government will lose a good man. An example may be quoted. Soon after the formation of the Agricultural and Forestry Research Institutes at Pusa and Dehra Dun, India, by Lord Curzon, a representative from each centre met by chance and discussed prospects. In reply to some remark, the Pusa man ejaculated, "Yes, your position is very different. You belong to a Service. We at Pusa do not." Dehra Dun was staffed from the Indian Forest Service. The Pusa specialist returned home shortly afterwards and was a great loss. That conversation took place more than twenty years ago!

A possible way out of this difficulty, it may be suggested, would appear to be to appoint each specialist research officer (for example, of the type serving in Malaya and Tanganyika) to one or other of the scientific or technical services (to which his investigations most nearly correlate) and then second him for research work, on the understanding that his service would be spent on such work : much as Royal Engineer and Military Medical officers are seconded for civil duty and remain seconded for the rest of their service. High salaries, higher than the Colonial Office could afford to offer, will not tempt, or if tempted retain, the right stamp of man unless the social conditions of life are assimilated to those of the Services. Incorporated in a Service, seconded with staff pay as specialised research officers, would, it is believed, remove the existing disabilities and secure in increasing numbers the type desired for this increasingly important work. The Committee thus alludes to this work:

No. 3164 , VoL. 125] 
" On the economic side we have to bring to bear the latest results of scientific research on the development of wealth, which is important, not only to the Colonies themselves but also to the Empire and the World. Most of the greater problems of the Colonies to-day are problems of Applied Science."

Possibly, however, the Committee wishes the research service to be a separate entity, under the general administrative control and supervision and responsible alone to an officer at the Colonial Office, linked through him with the various Imperial Bureaux which have recently been established, and through them with the British Dominions. This is the underlying assumption in the various reports on colonial research to which the Committee refers, and particularly that of the sub-committee which reported to the Colonial Office Conference of 1927 on the possibilities of the creation of a Colonial Scientific and Research Service, available for the requirements of the whole Colonial Empire ; in other words, the creation of an Imperial Service, financed out of an Imperial fund, to replace a number of water-tight provincial services which have too long been dependent on individual Colonial governments, most of which have hitherto given little indication of their appreciation of the value of long-range research.

\section{How Fire Became Known.}

Myths of the Origin of Fire: an Essay. By Sir James George Frazer. Pp. vii +238. (London : Macmillan and Co., Itd., 1930.) 12s. 6d. net.

A NEW book by Sir James Frazer is assured of a cordial welcome, both on account of the exhaustive compilation of material which is rendered easily accessible to readers, and by reason of the charming literary style in which the collected data are placed on record and discussed. The problems which are suggested by the mass of facts brought together and collated are without question intriguing. In the present instance Sir James has set him. self the task of collecting together for comparative study the various myths and legends which serve to explain to the primitive mind the way in which fire became known to mortals, and how, later, a knowledge was acquired of the means of producing fire at will. Man, without doubt, was acquainted with and made use of fire, as kindled by natural processes, long prior to his discovery of the fact that it was possible to make fire by artificial means whenever occasion demanded. Sir James even suggests a phase when man was "ignorant of the use or even of the existence of fire ", and discusses the problem in terms of three successive phases, (1) the Fireless Age, (2) the Age of Fire Used, (3) the Age of Fire Kindled-phases which appear to be suggested by a study of the beliefs in regard to the origin of fire. While the latter two phases are readily acceptable, as coming within the period of early human culturedevelopment, it is less easy to imagine even the most primitive members of the genus Homo having been entirely unacquainted with fire as a phenomenon in Nature. There is no evidence to prove that Nature did not cultivate the incendiary habit until man was already specialised as Man and had become differentiated from the rest of the animal kingdom. His forerunners must already have experienced Nature-kindled fire and must have learned to respect, or at any rate fear it. It seems very unlikely that even proto-man could have completely lacked such experiences, and it becomes difficult to credit a human phase involving complete ignorance of fire.

In nearly all the myths of the origin of fire as an accessory to human culture, the supernatural plays an important part, and the pre-scientific attempts of primitive minds to interpret the phenomenon of fire naturally do not show any inkling of its true nature. In a strikingly large number of the legends, fire is reputed to have been stolen for man's use, usually from some supernal possessor ; and, similarly, knowledge of the art of making fire has been very widely believed to have been obtained by trickery. So wide-spread among primitive peoples is this belief in the original theft of fire, that it appears highly probable that the Promethean myth of the ancient Greeks, with its closely similar record of the purloining of fire from Zeus, or from Hephæstus, was inherited as a traditional story handed down from a remote past, undergoing variation in detail to adapt it to local environmental and culture conditions. It appears far more probable that this fire-legend of Prometheus was a slightly modified descendant from an ancient and widely diffused folk-tale, than that in it we see the prototype of a myth which spread from a centre of advanced culture and became disseminated among a vast number of heterogeneous and widely separated peoples of low culture.

Prometheus, according to the legend, carried the

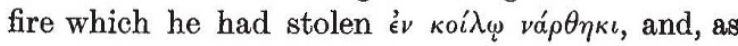
Sir James says (p. 195), the narthex " is commonly identified with the giant fennel. ..." $\mathrm{He}$ expresses doubt as to Theodore Bent's suggestion that the narthex was a reed inside which the smouldering tinder was carried "to prevent its being blown out" ("Cyclades", p. 365). The reason given for this

No. 3164, VoL. 125] 